\section{Jugoslav Aničić ${ }^{1}$}

Union University - Nikola Tesla,

Faculty of Entrepreneurial Business, Belgrade

\section{Miloje A. Jelić ${ }^{2}$}

High Business School, Niš

\section{Borivoje B. Prokopović ${ }^{3}$}

High Business School, Niš
SCIENTIFIC REVIEW ARTICLE doi:10.5937/ekonomika1604167A Received: November 08, 2016 Accepted: December12, 2016

\title{
APPLYING FAIR VALUE ACCOUNTING IN MAKING FINANCIAL REPORTS IN SERBIA
}

\begin{abstract}
Applying of fair value accounting is primarily put into operation to satisfy investor's needs for information. The basic idea here is that balance sheet represents the economic reality, which means that assets, obligations and capital are expressed at fair value, which in terms of active and liquid market best reflects market prices. The effects of applying fair value are reflected through the income statement and thus measurement results become a consequence of capital measurement.

In conditions of stable prices and an active market, applying fair value is not accompanied by bigger problems. The reason behind this is that valuation of assets and liabilities are carried out at current market prices. The problem occurs in conditions of inactive and illiquid markets. In this circumstances, estimating according to fair value requires the use of different assessment techniques, which represent a potential source of inaccuracy.

Furthermore, by applying fair value in times of financial crisis the problem of procyclical effects can occur. The growth of financial markets and prices encourages the purchase of securities at higher prices. This can contribute to the creation of speculative bubbles, and in times of crisis and fall in prices may encourage sale at lower prices, deepening the crisis.
\end{abstract}

Key words: fair value, historical costs, financial reporting

JEL Classification: M21, M41 i 031, 032

\section{ПРИМЕНА РАЧУНОВОДСТВА ФЕР ВРЕДНОСТИ У ИЗРАДИ ФИНАНСИЈСКИХ ИЗВЕШТАЈА У СРБИЈИ}

\section{Апстракт}

Примена рачуноводства фер вредности је приоритетно стављена у

\footnotetext{
1.ajugoslav@yahoo.com

2 jelic.m@open telekom.rs

${ }^{3}$ boraprokopovic@gmail.com
} 
функиију информационих потреба инвеститора. Основна идеја при томе је да биланс изрази економску стварност, ито значи да имовину, обавезе и капитал изрази по фер вредностима, које у условима активног и ликвидног тржишта најбоље одражавају тржишне иене. Ефекти примене фер вредности се рефлектују преко биланса успеха и на тај начин мерење резултата постаје последица мерења капитала.

Примена фер вредности није праћена већим проблемима у условима постојања стабилних иена и активног тржишта јер се вредновање имовине и обавеза одвија по актуелним тржишним ценама. Проблем се јавља у условима неактивних и неликвидних тржишта јер тада процењивање по фер вредности захтева примену различитих техника прочењивања што представља потенцијални извор непрецизности.

Осим тога, у условима финансијске кризе примену фер вредности прати проблем проиикличног дејства јер у условима раста финансијских тржишта и растућих иена подстиче куповину хартија од вредности по вишим иенама, доприносећи стварању шпекулативних балона, а у условима кризе и пада цена може подстицати продају по нижим ценама, продубљујући постојећу кризу.

Кључне речи: фер вредност, историјски трочкови, финансијско извештаване

\section{Introduction}

The imperfection of financial markets, complexity of business situations, variety of business and financial statements user's needs affect the constant improvement of financial reporting model, but it is quite clear that in such circumstances there is no perfect, theoretically consistent and universally applicable model to successfully solve all the problems of measurement, expressing and presenting the achievements of business entities.

There are many questions related to this issue that are put upon accounting practices. The bigest one being whether to provide information relevant to deciding, which can often contain unreliable values, or to provide accurate and reliable information, but because of its untimeliness could lose its importance for decision-making.

Business entities in our country are also faced with a similar dilemma: is it better for them to perform assessment, or not, whether is the assessment required, what is the comparative practice in the European Union, opinions and actions of the auditing professionals about these issues and the like.

The European accounting doctrine supports the historical cost principle and the recognition of gains that have been achieved in the market and International Financial Reporting Standards (IFR) are in favor of applying accounting based on fair value.

\section{Basic requirements of IFRS regarding the assessment at fair value}

IFRS accounting standards are created and introduced to achieve uniformity and transparency of financial statementst on any economic entity, regardless of the activity and 
the country of origins.

The general rule is that the greater importance is given to accounting and financial reporting in developed economies. The reason for this is that the investors are opting for the markets which are familiar and which they believe in. This is the main reason why they have more confidence in those countries that have adopted and consistently accepted accounting standards for financial reporting.

The importance and usefulness of financial statements should not be valuated only in relation to individual users (eg, investors and creditors), but also from a wider economic perspective, ie. from a social point of view. This is because financial reporting, in addition to a number of other relevant factors, must include in its primary goals the provision of the highest possible level of social welfare, which is the supreme strategic goal of every society. In other words, the quality of financial reporting of the state, is directly proportional and corresponded (in the long run) to the general economic situation in the country.

The goal of IFRS is versatile, easier and better understanding of the financial statements with the mission to provide data and information for comparative analysis and successful business communication for faster flow of goods and capital. IAS/IFRS are instruments for the harmonization of the various accounting regulations relating to the preparation and presentation of financial statements that serve as the basis for economic decision-making.

The adoption of optimal business decisions contributes to optimal location of limited economic resources and thus the over all economic growth of the national economy. Also, the efficiency of the capital market is directly dependent on the quality of available information, their usefulness and relevance for decision-making. A direct consequence of efficient capital markets are sufficient capital resources that enable economic entities to define and implement the optimal policy of financing their business transactions. All this leads to a healthy national economy and overall, sustainable economic growth and development. So, if there is quality and reliable accounting and financial reporting that is characterized by the usefulness of information, quality business decisions, efficiency of capital markets, the sufficiency of funding sources and a healthy economy - it can create the very realistic assumption for increasing the level of social welfare which is the target functions in every society.

Questions about estimates are defined by IAS 16 - Property, Plant and Equipment and IAS 40 - Investment property. Legal enteties, on the basis of IAS 16, have a right to assessment or subsequent measurement after initial recognition of fixed assets, could be carried at cost or fair value. In this case the chosen method is determined by the rules on accounting and accounting policies and applied are consistently in a longer period of time.

\section{Applying of fair value accounting in the European Union}

Representation of fair value accounting in the Member States of the European Union is through ICAEW's (Institute of Chartered Accountants in England and Wales) research for the European Commission. The study was published in 2007 entitled "EU Implementation of IFRS and the fair value directive - A report for the European Commision."

Research topic of this study is the use of IFRS in the financial statements of companies in the EU. Quoted companies in the EU, whose securities are traded on the stock exchange in its consolidated statements, have to apply IFRS since 2005. Part of this study that dealt with 
the application of fair value is about the 200 largest companies in the EU countries, whose securities are traded on the stock market, and whose financial reporting is in accordance with IFRS.

The general conclusion of this study is that "the use of fair value accounting in accordance with IFRS is less wide spread than previously assumed, especially if the companies are given the opportunity to use the cost model or the fair value model, they will use the cost model".

Table.1. Essessment of Property, Plant and Equipment in EU

\begin{tabular}{|l|c|c|}
\hline The cost model of fair value & $\begin{array}{c}\text { Number of } \\
\text { companies }\end{array}$ & Percent \\
\hline The cost model for all property, plant and equipment & 191 & $95,5 \%$ \\
\hline Revaluation model for all property, plant and equipment & - & - \\
\hline $\begin{array}{l}\text { Revaluation model for all property, the cost model for } \\
\text { all plant and equipment }\end{array}$ & 5 & $2,5 \%$ \\
\hline $\begin{array}{l}\text { Revaluation model for some properties, cost model for } \\
\text { the rest properties and all plant and equipment }\end{array}$ & 3 & $1,5 \%$ \\
\hline $\begin{array}{l}\text { Without any property, plant and equipment } \\
\text { Sum }\end{array}$ & 1 & $0,5 \%$ \\
\hline
\end{tabular}

The results of this research show that about $96 \%$ of companies, which use IFRS in their financial statements, estimate its fixed assets by cost model, by buying value or by cost and not by fair value. About 4\% of European companies fair value assessment use only in case of properties, but not for plants and equipment.

Also, the Chamber of Chartered Tax Advisors in most countries of the European Union refuse the extension of application of IFRS with companies whose securities are listed on the capital markets on all other companies.

\section{Effects of applying fair value accounting}

Business entities independently decide on the applying of fair value to present their fixed assets. They use a general act which must be in accordance with international and domestic accounting regulations. It is important to look at the positive and negative effects and assess the financial statements.

The most significant positive effects of valuation at fair value for the companies are:

- improving the property and financial position of the company in the financial statements as the assessment leads to an increase in the value of fixed assets and total assets and liabilities increase in revaluation reserves and capital of the company;

- reduction of taxable profits in sales of fixed assets, as the assessment at fair 
value increases value of fixed assets, thus reducing the gain on sale of fixed assets. This gain is determined as the difference between the realized selling price and the current carrying value;

- reduction of debt of the company due to an increase in the value of fixed assets compared to liabilities;

- $\quad$ ability to use the revaluation reserves, which occurs at the moment of disposal of fixed asset (sale, debiting etc.), so that they are transferred to retained earnings from previous years. They can be used to cover losses from previous years and other purposes in accordance with applicable legislation.

In assessing the fixed assets at fair value IAS 16 does not permit selective enforcement, in the sense that it is not possible to assess a single fixed asset but for the other asset, to use the cost model. The decision to perform assessments of fixed assets refers to all assets belonging to the appropriate group ( equivalent assets of a similar nature and usage in business entity).

\section{Reasons against applying of fair value}

The largest negative effects for businesses resulting from the application of fixed assets at fair value are:

- reduction of the gain in the income statement due to the increasing cost of accounting depreciation whis is arising directly from the increase in fixed assets.

- company can increse in size. This can reslut in the transformation for small to legal medium entity, which in turn causes the loss of benefits that are designed for small businesses;

- there is no improvement in basic financial indicators of the company - the liquidity and solvency;

- there is no impact on the amount of tax depreciation;

- there is no impact on the amount of taxable capital gain

- collision with the accounting principles of prudence, which is required by the Fourth Directive of the EU, and by which the assets in the balance sheet are valued at the lower value and liabilities at a higher value. This is opposed to fair value, and the principle of realization, because the assessment of investment properties at fair values recordes revenues that have not yet been confirmed in the market (investment property is not sold);

- financial statements become a conglomerate of different values and, consequently, lose their practical value because the fixed assets and securities (other than those held to maturity) are stated at fair value and other items at bying cost, cost or selling price, etc.

When opting for fair value accounting it should be taken into considiration the costs of the assessment, particularly with the involvement of external assessors. In our country there is no professional title of certified appraiser, so the risk of inaccurate assessment and the possibility of its denial by the auditors is very large. Assessments in our country are done by auditing companies, forensic experts, rating agencies and others. 
Companies in EU that apply IFRS do not use assessment of fixed assets at fair value. Because our country is in the process of harmonizing its legislation with EU standards and regulations, many use this fact as the main argument in (not) applying fair value accounting in financial statements

When determining which accounting policy to apply, our economic operators need to bear in mind the impact of inflation on the value of their fixed assets, particularly on real estate.

Inflation in our country in previous years is far greater than inflation in the EU countries and there is a real opportunity for presentation of financial statements that do not reflect economic reality, namely, that the carrying value of property is greatly underestimated. This especially applies to property, constructed or acquired in the $90 \mathrm{~s}$ in conditions of major inflationary rate.

Our economic operators must bear in mind that the financial reporting system is one of the key elements of corporate governance, which significantly affects the performance of companies, financial markets and thus the entire national economy. Without good corporate governance there is no long-term competitiveness of companies, their market position and results are weak and, consequently, companies are becoming ideal ground for corruption.

Applying of fair value in accounting policy of the economic entities opens many important questions. How does applying of fair value accounting reflects the quality of financial statements? What are the implications of applying fair value to investors, companies, managment and key stakeholders? Does the applying of fair value is favorable regulatory bodies? Does the applying of fair value increases management responsibilities for maintaining adequate business policy? Is the problem of applying of fair value only in measuring the value or is it also the problem of distribution of profit?

\section{Conclusions}

The basic idea of applying fair value in the financial reporting process is the need that the balance sheet reflects current economic reality, which includes presentation of assets, liabilities and equity at current market values that reflect the expected cash flows at the balance sheet date.

Applying of fair value in the foreground puts information interests of investors in analyzing the current financial position of the entity. In this context, the creators of accounting standards promote applying of the concept of fair value in order to come up with the concept of evaluation that will meet two requirements: "a good theoretical concept which can be successfully applied in practice." Since the market is not perfect, it often becomes inactive and illiquid, especially in times of economic crisis, there is a legitimate question to what extent the previous two can successfully be met.

Business entities in the Republic of Serbia, bearing in mind the necessary harmonization of accounting regulations with the EU, independently decide on the applying of fair value accounting in the financial reporting process. Applying of fair value accounting brings the number of positive, but also negative effects.

Business entites should evaluate each effect separately and bring the accounting policies that are most favorable to them, looking at the impact of positive and negative effects over a period of several years. 


\section{References}

Laux, C., Leuz, C(2009)., The crisis of fair-value accouting: Making sense of the recent debate, Accounting, Organizations and Society.

Milojević, D. (2006), Revizija finansijskih izveštaja, Fakultet za trgovinu i bankarstvo, Beogradska bankarska akademija, Beograd.

Aničić J.(2009), Finansijsko izveštavanje u Srbiji u tranzicionom periodu, Fakultet za preduzetnički biznis Beograd.

Savez računovođa i revizora Srbije. (2007). Napomene uz finansijske izveštaje. Računovodstvena praksa, 2-3, 242-256.

Wilson, R.M.S.-Me Hugh, G.: Financial Analysis-A Menagerial Introduction.

Todorović Z. (2002) Potreba i mogućnosti korišćenja MRS u Jugoslaviji.

Robson,A. P.(1966):Essential Accounting for Managers, Cassel Publishers Ltd., London, S. Đorđević: (2007) Primena međunarodne profesionalne računovodstvene regulative, SRRS, Zlatibor.

Weston,J.F., Brighman, E.F.: Menagerial Finance, fourth edition, Holt, Reinhart and Winston, Ine., London.

Bešlić, D. (2011). Harmonizacija finansijskog izveštavanja - dometi i ograničenja za preduzeća u Srbiji. Visoka poslovna škola strukovnih studija Novi Sad.

Božac M.G(2002).Planiranje strategijskih ciljeva poduzeća. Ekonomski pregled, 53(5-6), 525-536.

Milojević, D.(2006), Revizija finansijskih izveštaja, Beograd, .

Novićević B.,Dejan J(2007). : Međunarodni standardi finansiskog izveštavanja, SRRS Beograd .

Berstein,L.A., Wild, J.J (2000).: Analysis of Financial Statements, MeGraw-Hill, New York.

Aničić J., Oblici finansiranja Preduzeća u Srbiji- prednosti i nedostaci, Fakultet za preduzetnički biznis Beograd, 2009.

Stojanović M.Finansijski izveštaji kao osnov formiranja ciljne dobiti.Zbornik radova Zlatibor 2007.

Prokopović B. \& Prokopović Ž.(2005), Finansijsko računovodstvo i bilansi. Beograd .

Ranković J.:(2003) Teorija bilansa, Ekonomski fakultet, Beograd.

Hampton,J.J (1989)., Financial Desisentice-hall, Ine, New Jersey,1989.

Knežević G .(2007), Ekonomsko-finansijska analiza, FFMO, Beograd .

Ivanišević M., Krasulja K. (1999), Poslovne finansije, Beograd.

J. Bogićević, V. Domanović i B. Krstić; Uloga finansijskih i nefinansijskih indikatora performansi u oceni održivosti preduzeća, Ekonomika br. 3/16.

D. Mihajlović, S. Stanković, M. Nikolić; Analiza finansijske ravnoteže kao osnove upravljanja kompanijom, Ekonomika br. 1/15.

Ž. Milojević, A. Damnjanović, S. Milovanović; Povećanje konkurentnosti preduzeća investiranjem u inovacije i nove tehnologije, Ekonomika br. 4/15 